\title{
Cikkismertetés: Árcsökkentés vagy médiakampány növeli jobban a zöldség- és gyümölcsfogyasztást?
}

\author{
Article review: Are mass media campaigns or price reductions more \\ effective in increasing fruit and vegetable intake?
}

$\begin{array}{ll}\text { Ismertető: } \quad \text { Kaposvári Csilla } \square \\ & \text { Nemzeti Népegészségügyi Központ }\end{array}$

Ismertetett cikk: Pearson-Stuttard J, Bandosz P, Rehm CD, et al: Comparing effectiveness of mass media campaigns with price reductions targeting fruit and vegetable intake on US cardiovascular disease mortality and race disparities. Am J Clin Nutr 2017;106:199-206. doi: 10.3945/ajen.116.143925

Beküldve: 2019.07.09.

doi: $\quad$ 10.24365/ef.v60i4.498

Kulcsszavak: zöldség- és gyümölcs fogyasztás; összehasonlító elemzés; táplálkozáspolitika; egyenlőtlenségek

Keywords: fruit and vegetable consumption; comparative analysis; nutrition policy; inequity

\section{HÁTTÉR}

Az Amerikai Egyesült Államokban (USA) az alacsony zöldség- és gyümölcsfogyasztás a szív- és érrendszeri megbetegedések egyik fontos rizikófaktora. A médiakampányok és a gazdasági ösztönzők egyaránt növelhetik a lakosság zöldség- és gyümölcsfogyasztását. A kétféle intézkedés egymáshoz viszonyított hatékonyságáról azonban kevés adat áll rendelkezésre. Az ismertetett kutatás célja az volt, hogy megbecsüljék az USA lakosságának körében a zöldség- és gyümölcsfogyasztás növelését célzó médiakampányok, és a fogyasztói árcsökkentés hatására bekövetkező szív- és érrendszeri halálozás csökkenését, valamint az etnikai egyenlőtlenségek változását.

\section{MÓDSZER}

A szerzők kifejlesztették az „USA élelmiszerpolitikai hatásmodellt" (US IMPACT Food Policy Model) annak érdekében, hogy a felnőtt amerikai lakosság körében a zöldség- és gyümölcsfogyasztás növelését célzó beavatkozások hatását össze tudják hasonlítani a 2015 és 2030 közötti időszakban. A három vizsgált szakpolitika a médiakampány, illetve a zöldség és a gyümölcs fogyasztói árának 10\%-os, valamint 30\%-os csökkentése volt az USA-ban. $A z$ árcsökkentés zöldség- és gyümölcsfogyasztásra gyakorolt hatásának mértékét egy korábbi metaanalízis eredményeire alapozták, amely szerint a zöldség és a gyümölcs árának minden 10\%-os csökkentése megközelítőleg 14\%-kal (95\% megbízhatósági tartomány: 11-17\%) növelte a lakosság zöldség- és gyümölcsbevitelét. A médiakampány jövőbeni hatását egy másik korábbi metaanalízis eredménye alapján becsülték meg. E szerint az olyan médiakampányok, mint pl. az „5x egy nap” elnevezésű, 7\%-kal (95\% megbízhatósági tartomány: 4-9\%) emelte meg a zöldség- és gyümölcsfogyasztást. A szerzők a modellezés során figyelembe vették a kiindulási táplálkozási szokásokban tapasztalt különbségeket, a szív- és érrendszeri halálozási arányokat, a médiakampány lefedettségét és időtartamát, valamint annak halványuló hatását az 
évek során. A kimeneti változók a megelőzött, vagy késleltetett kumulatív szív- és érrendszeri halálozás (koronáriabetegség és sztrók) és a megnyert életévek (life-years gained) voltak a vizsgált időszakban kor, nem és etnikai hovatartozás szerinti bontásban.

\section{EREDMÉNYEK}

Egy 2015-ben lefolytatott 1 éves médiakampány kb. 7\%-kal növelte volna a lakosság átlagos zöldségés gyümölcsfogyasztását, ami 18.600 szív- és érrendszeri halálesetet előzhetett volna meg (95\% megbízhatósági tartomány: 17.600-19.500), valamint 280 ezer életévet nyert volna 2030-ig. Egy 15 évig tartó médiakampány hatására a zöldségés gyümölcsfogyasztás emelkedése fenntarthatóvá válna, ami háromszor nagyobb mértékben csökkentené a szív- és érrendszeri halálozást (56.100; 95\% megbízhatósági tartomány: 52.400-57.700). Ezzel összevetve, a 10\%-os fogyasztói árcsökkentés a zöldség- és gyümölcsfogyasztást 14\%-kal növelné meg. Ez mintegy 153.300 (95\% megbízhatósági tartomány: 146.400-159.200) szív- és érrendszeri halálesetet előzne meg, és 2,51 millió megnyert életévet jelent. Míg a 30\%-os árcsökkenés hozadéka a zöldség- és gyümölcsfogyasztás 42\%-os növekedése lenne, ami 451.900 szív- és érrendszeri halálesetet előzne meg vagy odázna el, és 7,3 millió megnyert életévet jelent. Ezek a hatások hasonlóan érvényesültek nők és férfiak esetében. Korcsoportok szerint vizsgálva arányaiban kisebb, de nagyobb abszolút hatást mértek az idősebbeknél. Kiemelendő, hogy a médiakampány növeli az etnikai alapú egészségegyenlőtlenségeket a nem latin-amerikai színesbőrű lakossági csoportok esetében, mivel annak hatásfoka a szív- és érrendszeri halálozás megelőzésében 35\%-kal alacsonyabb volt, mint a fehér lakosság körében. Ezzel szemben az árcsökkentést alkalmazó szakpolitikák hatására csökkentek az etnikai egészségegyenlőtlenségek.

A szerzők azt a következtetést vonták le, hogy bár mindkét beavatkozás - a zöldségek és a gyümölcsök fogyasztói árának csökkentése és a médiakampány - javítja a szív- és érrendszeri halálozások mutatóit, az árcsökkentéssel nagyobb mértékű és fenntarthatóbb egészséghatások érhetők el.

\section{TANULSÁGOK HAZAI SZAKEMBEREK SZÁMÁRA}

Hazánkban is szükséges lenne megismerni a lakosság zöldség- és gyümölcsfogyasztásának növelését célzó különböző kampányok és más típusú beavatkozások, szakpolitikák hatékonyságát. Az egészséges élelmiszerek, így a zöldségek és a gyümölcsök árának csökkentését célzó intézkedések is felmerülhetnek kiegészítő intézkedésként az egészségtelen termékekre kivetett adók mellett. 